\title{
PENERAPAN KONSEP UTILITARIANISME UNTUK MEWUJUDKAN PERLINDUNGAN KONSUMEN YANG BERKEADILAN KAJIAN PERATURAN OTORITAS JASA KEUANGAN NOMOR: 1/POJK.07/2013 TENTANG PERLINDUNGAN KONSUMEN SEKTOR JASA KEUANGAN
}

\author{
Dwi Edi Wibowo \\ Ilmu Hukum, Fakultas Hukum, Universitas Pekalongan \\ e-mail: unikaljaya2018@gmail.com
}

\begin{abstract}
Abstrak: Peranan internet dalam teknologi informasi telah digunakan untuk mengembangkan industri keuangan (financial industry) melalui modifikasi dan efisiensi layanan jasa keuangan yaitu dikenal dengan istilah Financial Technology atau Fintech. Fintech jenis pinjam-miminjam uang berbasis teknologi atau peer to peer lending (P2Plending) merupakan jenis Fintech yang tumbuh pesat di Indonesia, kelebihan pinjam meminjam uang melalui layanan P2P-lending lainnya adalah syarat yang sangat mudah dan proses yang cepat dibandingkan meminjam uang melalui Lembaga Bank. Namun kemudahan transaksi yang ditawarkan oleh layanan P2P- lending justru memperlemah posisi dari konsumen. Permasalahan Bagaimanakah Penerapan Konsep Utilitarianisme Untuk Mewujudkan Perlindungan Konsumen Fintech. (Financial Technology) Yang Berkeadilan, Tujuan untuk mengetahui bagaimanakah penerapan konsep utilitarianisme untuk mewujudkan perlindungan kosnumen fintech ( finansial technology yang berkeadilan
\end{abstract}

Kata kunci : utilitarianisme, perlindungan konsumen, berkeadilan

\begin{abstract}
Abstrak: The role of the internet in information technology has been used to develop the financial industry through the modification and efficiency of financial services, known as Financial Technology or Fintech. Fintech borrows money based on technology or peer to peer lending (P2P-lending) is a fast-growing type of Fintech in Indonesia, the advantages of lending and borrowing via other P2P-lending services are very easy conditions and a fast process compared to borrowing money through Bank Institution. But the ease of transactions offered by P2P-lending services actually weakens the position of consumers. Problems How to Implement the Utilitarianism Concept to Realize Fintech Consumer Protection. (Financial Technology) that is just, the aim is to find out how the application of the concept of utilitarianism is to realize the protection of fintech consumers (equitable technology finance.
\end{abstract}

Keywords: utilitarianism, consumer protection, justice 



\section{Pendahuluan}

Perkembangan globalisasi yang sangat pesat telah membawa perubahan terhadap pola kehidupan masyarakat Indonesia. Perkembangan globalisasi informasi tersebut antara lain ditandai dengan berkembangnya teknologi internet. ${ }^{1}$

Peranan internet dalam teknologi informasi telah digunakan untuk mengembangkan industri keuangan (financial industry) melalui modifikasi dan efisiensi layanan jasa keuangan yaitu dikenal dengan istilah Financial Technology atau Fintech. . Fintech jenis pinjam-miminjam uang berbasis teknologi atau peer to peer lending (P2P-lending) merupakan jenis Fintech yang tumbuh pesat di Indonesia.

P2P-lending atau Layanan Pinjam Meminjam Uang Berbasis Teknologi adalah penyelenggaraan layanan jasa keuangan untuk mempertemukan pemberi pinjaman dengan konsumen.Perusahaan peer-topeer (P2P) lending atau pinjaman online

11 Abdul Halim Barkatullah dan Teguh Prasetyo, 2005, Bisnis E-commerce: Studi Sistem Keamanan dan hukum di Indonesia, Pustaka Pelajar, Yogyakarta, hlm 1. marak beroperasi di Indonesia sejak 2013. Kasus pinjol sempat mendapatkan pemberitaan yang cukup meluas pada Juni 2018 karena cara-cara penagihan yang tidak patut. Sejak bulan Mei yang lalu LBH Jakarta telah menerima pengaduan dari 283 korban pinjol dengan berbagai bentuk pelanggaran hukum., dan mengakibatkan seseorang di kenai PHK oleh perusahaan tempatnya bekerja, diceraikan oleh suami/istri mereka (karena menagih ke mertua), trauma (karena pengancaman, kata-kata kotor, dan pelecehan seksual). Akibat bunga yang sangat tinggi misalnya, banyak peminjam yang tidak mampu membayar akhirnya frustasi, mereka kemudian berupaya menjual organ tubuh (ginjal) sampai pada upaya bunuh diri. $^{2}$ Permasalahan bagaimanakah penerapan konsep utilitarianisme untuk mewujudkan perlindungan konsumen fintech. (Financial Technology) yang berkeadilan. Tujuan untuk mengetahui bagaimanakah penerapan konsep utilitarianisme untuk mewujudkan perlindungan konsumen fintech. (Financial Technology) yang

${ }^{2}$ Sumber dari LBH Jakarta, Nopember, 2018 
berkeadilan.Konsep

Utilitarianismeberkembang

pada pertengahan abad ke-17 sampai dengan abad ke-18. Adapun tokoh pemikir utama dari konsep ini antara lain Jeremy Bentham 1748-1832) dan John Stuart Mill (1806-1873). Pandangan utilitarianisme berangkat dari dua factor yang mempengaruhi perilaku manusia, yakni rasa sakit/penderitaan dan kepuasan/kebahagiaan. Faktor tersebut menentukan tindakan individu, terkait benar tidaknya tindakan yang dilakukan, serta sebab akibat dari tindakan itu sendiri. Dikatakan pula bahwa setiap individu selalu menginginkan kebahagiaan dan menghindari penderitaan. ${ }^{3}$, dengan demikian sebuah kebijakan yang berkeadilan sosial adalah kebijakan yang mampu menghasilkan pleasure atau total utility terbesar bagi masyarakat. Mill menegaskan bahwa tujuan utama suatu kebijakan adalah untuk memaksimalkan utilitas (kebahagiaan) bagi mayoritas masyarakat, dikarenakan setiap individu memiliki tujuan kebahagiaan yang berbeda, maka kebahagiaan bagi yang

3 Betham, Jeremy, An Introduction to the Principle of Morals and Legislation, Batoche Books, Kitchener, 2000) banyak (masyarakat) menjadi lebih penting daripada kebahagiaan bagi yang lebih sedikit (individu). ${ }^{4}$ Perlindungan Konsumen Menurut Undang-Undang No.9 Tahun 1999 Tentang Perlindungan Konsumen Pasal 1 ayat 1 bahwa perlindungan konsumen adalah segala upaya yang menjamin adanya kepastian hukum untuk memberi perlindungan kepada konsumen.Fintech berasal dari istilah financial technology atau teknologi finansial. Menurut The National Digital Research Centre (NDRC), di Dublin, Irlandia, mendefinisikan fintech sebagai “ innovation infinancial services" atau “inovasi dalam layanan keuangan fintech"merupakan suatu inovasi pada sektor finansial yang mendapat sentuhan teknologi modern.Transaksi keuangan melalui fintech ini meliputi pembayaran,investasi, peminjaman uang, transfer,rencana keuangan dan pembanding produk keuangan. ${ }^{5}$

\section{Pembahasan}

${ }_{4}$ Mill, John Stuart, Utilitarianisme, Batoche Books, Kitchener, 2001)

IIrma Muzdalifa, Inayah Aulia Rahma, Bella Gita Novalia, Peran Fintech Dalam Meningkatkan Keuangan Inklusif Pada UMKM di Indonesia, Jurnal Masharif al-Syariah: Jurnal Ekonomi dan Perbankan Syariah Vol. 3, No. 1, 2018 


\section{Tujuan Hukum Utilitarianisme}

Tujuan hukum adalah hukum dapat memberikan jaminan kebahagiaan kepada individu-individu, barulah kepada orang banyak. "the greatest happiness of the greatest number" (kebahagiaan yang sebesar-besarnya dari sebanyak-banyaknya orang). Prinsip ini harus diterapkan secara kuatitatif, karena kualitas kesenangan selalu sama, untuk mewujudkan kebahagiaan individu dan masyarakat maka perundang-undangan harus mencapai empat tujuan:

a. to provide subsistence (untuk memberi nafkah hidup);

b. to Provide abundance (untuls. memberikan nafkah makanan berlimpah);

c. to provide security (untuk memberikan perlindungan); dan

d. to attain equity (untuk mencapai persamaan).

Undang-undang yang banyak memberikan kebahagiaan pada bagian terbesar masyarakat akan dinilai sebagai undang-undang yang baik. Lebih lanjut Bentham berpendapat bahwa keberadaan negara dan hukum sematamata sebagai alat untuk mencapai manfaat yang hakiki yaitu kebahagiaan mayoritas rakyat. Ajaran Bentham yang sifat individualis ini tetap memperhatikan kepentingan masyarakat, agar kepentingan idividu yang satu dengan individu yang lain tidak bertabrakan maka harus dibatasi tidak terjadi homo homini lupus. Menurut Bentham agar tiap-tiap individu memiliki sikap simpati kepada individu lainnya sehingga akan tercipta kebahagiaan individu dan kebahagiaan masyarakat akan terwujud. Bentham menyebutkan"The aim of law is the greatest happines for the greatest number" 6

2.

. Teori Perlindungan Konsumen Prinsip-prinsip mengenai kedudukan konsumen dalam hubungan dengan pelaku usaha berdasarkan doktrin atau teori yang dikenal dalam perkembangan sejarah hukum perlindungan konsumen, antara lain :

a. Let the buyer beware (caveat emptor) Doktrin let the buyer beware atau caveat emptor merupakan dasar dari lahirnya sengketa dibidang transaksi konsumen. Asas ini berasumsi

\footnotetext{
${ }^{6}$ besar@binus.edu
} 
bahwa pelaku usaha dan konsumen adalah dua pihak yang sangat seimbang, sehingga konsumen tidak memerlukan perlindungan. Prinsip ini mengandung kelemahan, bahwa dalam perkembangan konsumen tidak mendapat informasi yang memadai untuk menen tukan Pilihan terhadap barang dan/atau jasa yang dikonsumsinya. Hal tersebut dapat disebabkan oleh keterbatasan pengetahuan konsumen atau ketidakterbukaan pelaku usaha terhadapproduk yang ditawarkannya. Dengan demikian, apabila konsumen mengalami kerugian, maka pelaku usaha dapat berdalih bahwa kerugian tersebut akibat dari kelalaian konsumen sendiri.

b. The due care theory Doktrin ini menyatakan bahwa pelaku usaha mempunyai kewajiban untuk berhati-hati dalam memasarkan produk, baik barang maupun jasa. Selama pelaku usaha berhati-hati dengan produknya, maka ia tidak dapat dipersalahkan. Pada prinsip ini berlaku pembuktian siapa mendalilkan maka dialah yang membuktikan. Hal ini sesuai dengan jiwa pembuktian pada hukum privat di Indonesia yaitu pembuktian ada pada penggugat, sesuai dengan pasal 1865 BW yang secara tegas menyatakan bahwa barangsiapa yang mendalilkan mempunyai suatu hak atau untuk meneguhkan haknya atau membantah hak orang lain, atau menunjuk pada suatu peristiwa, maka diwajibkan membuktikan adanya hak atau peristiwa tersebut.

c. The privity of contract Doktrin ini menyatakan pelaku usaha mempunyai kewajiban untuk melindungi konsumen, tetapi hal itu baru dapat dilakukan jika diantara mereka telah terjalin suatu hubungan kontraktual. Pelaku usaha tidak dapat disalahkan diluar hal-hal yang dperjanjikan. Dengan demikian konsumen dapat menggugat berdasarkan wanprestasi. Hal ini sesuai dengan ketentuan dalam pasal 1340 BW yang menyatakan tentang ruang lingkup berlakunya perjanjian 
hanyalah antara pihak-pihak yang membuat perjanjian saja. ${ }^{7}$

4.

\section{Teori Keadilan}

Dalam filsafat hukum, teori-teori hukum alam sejak Socrates hingga Francois Geny, tetap mempertahankan keadilan sebagai mahkota hukum. Teori Hukum Alam mengutamakan "the search for justice".7 Terdapat macammacam teori mengenai keadilan dan masyarakat yang adil. Teori-teori ini menyangkut hak dan kebebasan, peluang kekuasaan, pendapatan dan kemakmuran. Diantara teori-teori itu dapat disebut: teori keadilan Aristoteles dalam bukunya nicomachean ethics, teori keadilan sosial John Rawl dalam bukunya a theory of justice dan juga Ahmad Ali dalam Menguak Teori Hukum dan teori Peradilan.

\section{Pandangan Aristoteles tentang} keadilan terdapat dalam karyanya nichomachean ethics, politics, dan rethoric. Lebih khususnya, dalam buku nicomachean ethics, buku itu sepenuhnya ditujukan bagi keadilan yang berdasarkan filsafat umum

75Shidarta, Hukum Perlindungan Konsumen Indonesia, PT Grasindo, Jakarta, 2006, hal 61
Aristoteles, mesti dianggap sebagai inti dari filsafat hukumnya, "karena hukum hanya bisa ditetapkan dalam kaitannya dengan keadilan" 8

Dari pandangan Aristoteles diatas yang sangat penting bahwa keadilan mesti dipahami dalam pengertian kesamaan. Namun Aristoteles membuat pembedaan penting antara kesamaan numerik dan kesamaan proporsional. Kesamaan numerik mempersamakan setiap manusia sebagai satu unit. Inilah yang sekarang lazim di pahami tentang kesamaan dan yang dimaksudkan ketika dikatakan bahwa semua warga adalah sama di depan hukum. Kesamaan proporsional memberi tiap orang apa yang menjadi haknya sesuai dengan kemampuannya, prestasinya, dan sebagainya. Dari pembedaan ini Aristoteles menghadirkan banyak kontroversi dan perdebatan seputar keadilan. Lebih lanjut, dia membedakan keadilan menjadi jenis keadilan distributif dan keadila korektif. Yang pertama berlaku dalam hukum publik, yang kedua dalam hukum perdata dan

${ }^{8}$ Carl Joachim Friedrich, Filsafat Hukum Perspektif Historis, Bandung: Nuansa dan Nusamedia, 2004, h. 25 
pidana. Keadilan distributif dan korektif sama-sama rentan terhadap problema kesamaan atau kesetaraan dan hanya bisa dipahami dalam kerangkanya. Dalam wilayah keadilan distributif, hal yang penting ialah bahwa imbalan yang sama-rata diberikan atas pencapaian yang sama rata. Pada yang kedua, yang menjadi persoalan ialah bahwa ketidaksetaraan yang disebabkan oleh, misalnya, pelanggaran kesepakatan, dikoreksi dan dihilangkan.

Keadilan distributif menurut Aristoteles berfokus pada distribusi, honor, kekayaan, dan barang-barang lain yang sama-sama bisa didapatkan dalam masyarakat. Dengan mengesampingkan "pembuktian" matematis, jelaslah bahwa apa yang ada dibenak Aristoteles ialah distribusi kekayaan dan barang berharga lain berdasarkan nilai yang berlaku dikalangan warga. Distribusi yang adil boleh jadi merupakan distribusi yang sesuai degan nilai kebaikannya, yakni nilainya bagi masyarakat.

Di sisi lain, keadilan korektif berfokus pada pembetulan sesuatu yang salah. Jika suatu pelanggaran dilanggar atau kesalahan dilakukan, maka keadilan korektif berusaha memberikan kompensasi yang memadai bagi pihak yang dirugikan; jika suatu kejahatan telah dilakukan, maka hukuman yang sepantasnya perlu diberikan kepada si pelaku. Bagaimanapun, ketidakadilan akan mengakibatkan terganggunya "kesetaraan" yang sudah mapan atau telah terbentuk. Keadilan korektif bertugas membangun kembali kesetaraan tersebut. Dari uraian ini nampak bahwa keadilan korektif merupakan wilayah peradilan sedangkan keadilan distributif merupakan bidangnya pemerintah. ${ }^{9}$

Dalam membangun argumentnya, Aristoteles menekankan perlunya dilakukan pembedaan antara vonis yang mendasarkan keadilan pada sifat kasus dan yang didasarkan pada watak manusia yang umum dan lazim, dengan vonis yang berlandaskan pandangan tertentu dari komunitas hukum tertentu. Pembedaan ini jangan dicampuradukkan dengan pembedaan antara hukum positif yang ditetapkan dalam undangundang dan hukum adat. Karena, berdasarkan pembedaan

${ }^{9}$ Carl Joachim Friedrich, Filsafat Hukum Perspektif Historis, Bandung: Nuansa dan Nusamedia, 2004, h. 25 
Aristoteles, dua penilaian yang terakhir itu dapat menjadi sumber pertimbangan yang hanya mengacu pada komunitas tertentu, sedangkan keputusan serupa yang lain, kendati diwujudkan dalam bentuk perundang-undangan, tetap merupakan hukum alam jika bisa didapatkan dari fitrah umum manusia.

Sedangkan Rawls dalam bukunya a theory of justice menjelaskan teori keadilan sosial sebagai the difference principle dan the principle of fair equality of opportunity. Inti the difference principle, adalah bahwa perbedaan sosial dan ekonomis harus diatur agar memberikan manfaat yang paling besar bagi mereka yang paling kurang beruntung.

Istilah perbedaan sosialekonomis dalam prinsip perbedaan menuju pada ketidaksamaan dalam prospek seorang untuk mendapatkan unsur pokok kesejahteraan, pendapatan, dan otoritas. Sementara itu, the principle of fair equality of opportunity menunjukkan pada mereka yang paling kurang mempunyai peluang untuk mencapai prospek kesejahteraan, pendapat dan otoritas. Mereka inilah yang harus di beri perlindungan khusus.
Rawls mengerjakan teori mengenai prinsip-prinsip keadilan terutama sebagai alternatif bagi teori utilitarisme sebagaimana dikemukakan Hume, Bentham dan Mill. Rawls berpendapat bahwa dalam masyarakat yang diatur menurut prinsip-prinsip utilitarisme, orang-orang akan kehilangan harga diri, lagi pula bahwa pelayanan demi perkembangan bersama akan lenyap. Rawls juga berpendapat bahwa sebenarnya teori ini lebih keras dari apa yang dianggap normal oleh masyarakat. Memang boleh jadi diminta pengorbanan demi kepentingan umum, tetapi tidak dapat dibenarkan bahwa pengorbanan ini pertamatama diminta dari orang-orang yang sudah kurang beruntung dalam masyarakat.

Menurut Rawls, situasi ketidaksamaan harus diberikan aturan yang sedemikian rupa sehingga paling menguntungkan golongan masyarakat yang paling lemah. Hal ini terjadi kalau dua syarat dipenuhi. Pertama, situasi ketidaksamaan menjamin maximum minimum bagi golongan orang yang paling lemah. Artinya situasi masyarakat harus sedemikian rupa sehingga dihasilkan untung yang paling tinggi 
yang mungkin dihasilkan bagi golongan orang-orang kecil. Kedua, ketidaksamaan diikat pada jabatanjabatan yang terbuka bagi semua orang. Maksudnya supaya kepada semua orang diberikan peluang yang sama besar dalam hidup. Berdasarkan pedoman ini semua perbedaan antara orang berdasarkan ras, kulit, agama dan perbedaan lain yang bersifat primordial, harus ditolak.

Selanjutnya Rawls menegaskan, The first statement of the two principles reads as follows in a natural way. First, each person is to have an aqual right to the most extensive basic liberty compatible with a similar liberty for others. Second, social and economic inequalities are to be arranged so that they are both (a) reasonably expected to be to everyone ${ }^{e e}$ s advantage, and (b) attached to positions and offices open to all.Program penegakankeadilan yang berdimensi kerakyatan haruslah memperhatikan dua prinsipkeadilan, yaitu, pertama, memberi hak dan kesempatan yang sama atas kebebasan dasar yang paling luas seluas kebebasan yang sama bagi setiap orang. Kedua, mampu mengatur kembali kesenjangan sosial ekonomi yang terjadi sehingga dapat memberi keuntungan yang bersifat timbal balik (reciprocal benefits) bagisetiap orang, baik mereka yang berasal dari kelompok beruntung maupun tidak beruntung ${ }^{10}$

Dengan demikian, perbedaan menuntut diaturnya struktur dasar masyarakat sedemikian rupa sehingga kesenjangan prospek mendapat hal-hal utama kesejahteraan, pendapatan, otoritas diperuntukkan bagi keuntungan orang-orang yang paling kurang beruntung. Ini berarti keadilan sosial harus diperjuangkan untuk dua hal.: Pertama, melakukan koreksi dan perbaikan terhadap kondisi ketimpangan yang dialami kaum lemah dengan menghadirkan institusi-institusi sosial, ekonomi, dan politik yang memberdayakan. Kedua, setiap aturan harus memposisikan diri sebagai pemandu untuk mengembangkan kebijakan-kebijakan untuk mengoreksi ketidak-adilan yang dialami kaum lemah

${ }^{10} \mathrm{John}$ Rawls, A Theory of Justice, Cambridge, Massa Chusetts, The Belknap Press of Harvard University press, 1971, p.60. Lihat pula terjemahan ke bahasa Indonesia oleh Uzair Fauzan dan Heru Prasetyo,2006, Teori Keadilan, Dasar-dasar Filsafat Politik untuk Mewujudkan Kesejahteraan Sosial dalam Negara, cet-1, Yogyakarta: Pustaka Pelajar., h. 72 
6.

7. Kajian Peraturan Otoritas Jasa Keuangan Nomor : 1/POJK.07/2013 Tentang Perlindungan Konsumen

\section{Sektor Jasa Keuangan}

Otoritas Jasa Keuangan atau yang lebih dikenal dengan sebutan OJK berdasarkan Pasal 1 Angka 1 Undang Undang Otoritas Jasa Keuangan merupakan lembaga yang independen dan bebas dari campur tangan pihak lain, yang mempunyai fungsi, tugas, dan wewenang pengaturan, pengawasan, pemeriksaan, dan penyidikan sebagaimana dimaksud dalam undang undang Otoritas Jasa Keuangan tersebut. Pendorong dibentuknya lembaga pengawas sektor jasa keuangan yang salah satunya Otoritas Jasa Keuangan yakni untuk sektor jasa keuangan yang bekerja secara efisien sesuai dengan tuntutan dan kebutuhan masa sekarang. ${ }^{11}$ Oleh sebab itu berdasarkan Pasal 4 Undang -Undang Otoritas Jasa Keuangan tujuan pembentukan Otoritas Jasa Keuangan ini dipertegas yakni agar keseluruhan

11 Theresia Anita Christiani, 2016, Bank Indonesia dan Otoritas Jasa Keuangan Dalam Perspektif Hukum, Cahaya Atma Pustaka, Yogyakarta, hlm. 81. pencegahan kegiatan jasa keuangan di dalam sektor jasa keuangan terselenggara secara teratur, adil, transparan, dan akuntabel, serta mampu mewujudkan sistem keuangan yang tumbuh secara berkelanjutan dan stabil, dan mampu melindungi kepentingan Konsumen dan masyarakat.

Berdasarkan Pasal 4 Undang Undang Otoritas Jasa Keuangan bahwa :"Pembentukan Otoritas Jasa Keuangan memiliki tujuan yakni agar keseluruhan kegiatan di dalam sektor jasa keuangan dapat :

a. Terselenggara secara teratur, adil , transparan, dan akuntabel

b. Mampu mewujudkan sistem keuangan yang tumbuh secara berkelanjutan dan stabil

c. Mampu melindungi kepentingan konsumen dan masyarakat."

Tujuan pembentukan dari Peraturan Otoritas Jasa Keuangan Nomor 1/POJK.07/2013 tentang Perlindungan Konsumen di Sektor Jasa Keuangan yakni diharapkan agar Otoritas Jasa Keuangan dapat meningkatkan pengawasan terhadap sektor jasa keuangan dan 
mengoptimalkan

perlindungan

Konsumen di sektor jasa keuangan. ${ }^{12}$

Perlindungan Konsumen dilihat

dari Pasal 1 Angka 3 Peraturan Otoritas Jasa Keuangan Nomor

1/POJK.07/2013 tentang Perlindungan Konsumen Sektor Jasa Keuangan dan Pasal 1 Angka 1 Undang - Undang Nomor 8 Tahun 1999 tentabg Perlindungan Konsumen adalah suatu upaya untuk menjamin kepastian hukum terhadap Konsumen yang telah melaksanakan kewajibannya sebagai akibat telah dilanggarnya hak Konsumen oleh Pelaku Usaha Jasa Keuangan (PUJK). Tujuan perlindungan Konsumen di sektor jasa keuangan berdasarkan Penjelasan Umum Peraturan Otoritas Jasa Keuangan Nomor 1/POJK.07/2013 yaitu untuk menciptakan sistem perlindungan Konsumen yang andal, meningkatkan pemberdayaan Konsumen, dan menumbuhkan kesadaranPelaku Usaha Jasa Keuanganmengenai pentingnya perlindungan Konsumen sehingga

${ }^{12}$ Onker Sihombing, 2012, Jurnal Hukum Bisnis "Analisis Hukum Otoritas Jasa Keuangan dan Pengawasan Pasa Modal", Volume 31 No.1 Tahun 2012, hlm.16. mampu meningkatkan kepercayaan masyarakat pada sektor jasa keuangan. Berdasarkan uraian tersebut maka arti penting Perlindungan Konsumen bagi Sektor Jasa Keuangan yakni untuk meningkatkan kepercayaan Konsumen terhadap Pelaku Usaha Jasa Keuangan (PUJK) dalam menggunakan produk/jasa di sektor jasa keuangan. ${ }^{13}$

$$
\text { Penyelesaian sengketa }
$$

Konsumen di sektor jasa keuangan dapat diselesaikan melalui beberapa upaya yang dapat ditempuh, diantaranya:

a. Penyelesaian pengaduan yang dilakukan oleh Lembaga Jasa Keuangan (LJK) disebut dengan Internal Dispute Resolution (IDR)

b. Penyelesaian sengketa melalui lembaga peradilan atau lembaga di luar pengadilan (External Dispute Resolution), apabila Internal Dispute Resolution tidak tercapai.

c. Otoritas Jasa Keuangan akan memfasilitasi penyelesaian sengkta

13Jonker Sihombing, 2012, Jurnal Hukum Bisnis "Analisis Hukum Otoritas Jasa Keuangan dan Pengawasan Pasa Modal", Volume 31 No.1 Tahun 2012, hlm.16. 
Konsumen yang tidak dapat 2017 pun bukanlah aturan yang berlaku diselesaikan melalui Internal secara publik, karena aturan tersebut Dispute Resolution, apabila merupakan aturan internal. Aturan Lembaga Alternatif Penyelesaian Sengketa (LAPS) belum terbentuk atau sudah terbentuk namun tidak mampu melaksanakan tugasnya untuk menyelesaikan sengketa di sektor jasa keuangan.

Aturan mengenai jangka waktu menanggapi aduan dari Konsumen sendiri menurutnya akan berproses dengan sendirinya. Hal tersebut dikarenakan belum adanya aturan yang berlaku secara publik khususnya di dalam Peraturan Otoritas Jasa Keuangan Nomor 1/POJK.07/2013 tentang Perlindungan Konsumen Sektor Jasa Keuangan perihal jangka waktu dari Otoritas Jasa Keuangan menyampaikan tanggapannya atas aduan yang telah diterima dari Konsumen . Beliau mengatakan sebenarnya sudah ada aturan yang mengatur hanya saja baru berlaku di bulan Januari awal tahun 2017 yakni di dalam aturan internal Otoritas Jasa Keuangan berdasarkan Peraturan Dewan Komisioner (PDK). Berlakunya aturan tersebut di awal bulan Januari tersebut menjelaskan bahw

a Otoritas Jasa Keuangan akan memproses Pengaduan Konsumen dalam Jangka Waktu 30 hari untuk Kantor Pusat dan 40 hari untuk Kantor Regional / Daerah sejak dokumen lengkap. Dampak dari tidak diaturnya mengenai jangka waktu pemberian tanggapan atas aduan oleh Otoritas Jasa Keuangan dalam Peraturan Otoritas Jasa Keuangan Nomor 1/POJK.07/2013 tentang Perlindungan Konsumen Sektor Jasa Keuangan yakni hak Konsumen untuk memperoleh kenyamanan dan kepastian Informasi atas aduan yang telah disampaikan kepada Otoritas Jasa Keuangan untuk penyelesaian sengketa menjadi tidak tercapai, sehingga tidak tercapainya hak tersebut menyebabkan menurunnya tingkat kepercayaan Konsumen terhadap Otoritas Jasa Keuangan sebagai suatu institusi atau lembaga yang memiliki tujuan untuk melindungi 
kepentingan Konsumen di sektor jasa keuangan. ${ }^{14}$

8.

9. Penerapan Konsep Utilitarianisme Untuk Mewujudkan Perlindungan Konsumen Fintech. (Financial Technology) Yang Berkeadilan Dengan Melakukan Kajian Peraturan Otoritas Jasa Keuangan Nomor : 1/POJK.07/2013 Tentang Perlindungan Konsumen Sektor Jasa

\section{Keuangan )}

Sejak Januari 2018, Yayasan Lembaga Konsumen Indonesia (YLKI) telah menerima lebih dari 50 pengaduan kredit online. Kebanyakan dari keluhan yang disampaikan adalah cara menagih hingga sistem perhitungan bunga dan denda yang tidak jelas. Bentuk penagihan yang sering dilakukan adalah dengan cara mengancam hingga menagih lewat orang yang nomor selulernya ada di daftar kontak konsumen.

LBH Jakarta mengaku telah menerima pengaduan dari 283 korban

${ }^{14}$ Theresia Anita Christiani, 2016, Bank Indonesia dan Otoritas Jasa Keuangan Dalam Perspektif Hukum, Cahaya Atma Pustaka, Yogyakarta. pinjaman online, hingga Mei 2018 lalu. Meskipun sudah diatur pemerintah melalui Otoritas Jasa Keuangan (OJP), nyatanya masih banyak pihak yang mendatangi LBH Jakarta dan mengeluhkan berbagai macam hal terkait kasus pinjaman online ini. Misalnya saja seperti kasus pinjaman online yang sempat menggegerkan publik karena cara penagihan yang tidak pantas, dari pengaduan yang masuk ke LBH Jakarta, terdapat sejumlah temuan awal terkait kasus pinjaman online yang kerap terjadi.

Dilansir TribunWow.com dari website resmi LBH Jakarta, bantuanbukum.or.id berikut ini temuan awal LBH Jakarta mengenai kasus tersebut.

a. Penagihan dengan berbagai cara mempermalukan, memaki, mengancam, memfitnah, bahkan dalam bentuk pelecehan seksual;

b. Penagihan dilakukan kepada seluruh nomor kontak yang ada di ponsel konsumen/peminjam (ke atasan kerja, mertua, teman SD, dan lain-lain);

c. Bunga pinjaman yang sangat tinggi dan tidak terbatas; 
d. Pengambilan data pribadi Nomor : 1/POJK.07/2013 Tentang (kontak, sms, panggilan, kartu Perlindungan Konsumen Sektor Jasa memori, dan lain-lain) di telepon Keuangan diharapkan dengan adanya seluler (ponsel) peraturan tersebut maka kepentingan konsumen/peminjam; konsumen khususnya di sektor jasa

e. Penagihan baik belum waktunya dan tanpa kenal waktu;

keuangan akan terlindungi, peraturan atau kebijakan yang di buat oleh

f. Nomor pengaduan pihak pemerintah atau lembaga di dalamnya penyelenggara pinjaman online harus dimasukkan suatu konsep, yang yang tidak selalu tersedia; kita kenal dengan konsep

g. Alamat kantor perusahaan utilitarianisme, dimana konsep penyelenggara pinjaman online utilitarianisme berangkat dari dua factor yang tidak jelas;

h. Aplikasi pinjaman online yang yang mempengaruhi perilaku manusia, berganti nama tanpa yakni rasa sakit/penderitaan dan pemberitahuan kepada konsumen/peminjam selama berhari-hari namun bunga pinjaman selama proses kepuasan/kebahagiaan. Faktor tersebut menentukan tindakan individu, terkait benar tidaknya tindakan yang dilakukan, serta sebab akibat dari tindakan itu sendiri. Dikatakan pula bahwa setiap perubahan nama tersebut terus berjalan.

individu selalu menginginkan kebahagiaan dan menghindari penderitaan, dengan demikian sebuah Dengan adanya kasus Financial kebijakan yang berkeadilan sosial Technology dalam bentuk pinjaman adalah kebijakan yang mampu online yang sangat merugikan konsumen dan menyeret konsumen dalam kedudukan yang rendah, maka dikeluarkan kebijakan yang dikeluarkan oleh OJK ( Otoritas Jasa Keuangan ) yaitu Peraturan Otoritas Jasa Keuangan menghasilkan pleasure atau total utility terbesar bagi masyarakat. Mill menegaskan bahwa tujuan utama suatu kebijakan adalah untuk memaksimalkan utilitas (kebahagiaan) bagi mayoritas masyarakat, dikarenakan setiap individu 
memiliki tujuan kebahagiaan yang Nomor 1/POJK.07/2013 tentang berbeda, maka kebahagiaan bagi yang Perlindungan Konsumen Sektor Jasa banyak (masyarakat) menjadi lebih Keuangan yakni tidak tercapainya hak penting daripada kebahagiaan bagi yang Konsumen untuk memperoleh lebih sedikit (individu).

\section{Penutup}

\section{Simpulan}

Peraturan Otoritas Jasa kenyamanan dan kepastian informasi mengenai tindak lanjut atas aduan yang telah disampaikan kepada Otoritas Jasa Keuangan untuk penyelesaian sengketa Keuangan Nomor 1/POJK.07/2013 tentang Perlindungan Konsumen Sektor Jasa Keuangan ditinjau dari tujuannya untuk memberikan perlindungan kepada Konsumen masih belum optimal, karena tidak diaturnya mengenai jangka waktu pemberian tanggapan oleh Otoritas Jasa Keuangan dari aduan yang telah disampaikan Konsumen dalam peraturan tersebut. Pengaturan mengenai jangka waktu tersebut dapat ditemukan di dalam aturan Internal Otoritas Jasa Keuangan yakni berdasarkan Peraturan Dewan Komisioner (PDK). Peraturan Dewan Komisioner (PDK) merupakan aturan yang tidak berlaku secara publik atau tidak dipublikasi terhadap masyarakat, sehingga dampak yang timbul dari tidak diaturnya jangka waktutersebut dalam Peraturan Otoritas Jasa Keuangan tersebut menyebabkan menurunnya tingkat kerpercayaan Konsumen terhadap Otoritas Jasa Keuangan sebagai institusi atau lembaga yang memiliki tujuan untuk melindungi kepentingan Konsumen di sektor jasa keuangan, dari kajian Peraturan Otoritas Jasa Keuangan Nomor 1/POJK.07/2013 Tentang Perlindungan Konsumen Sektor Jasa Keuangan belum maksimal memasukan konsep utilitarianisme, kalau di lihat dari tujuan peraturan tersebut memang sudah untuk kenyaman dan kebahagaian konsumen secara luas, tidak hanya konsumen secara individual, luas di sini bisa diartikan konsumen yang meminjam uang dengan pinjaman online, tetapi dalam peraturan tersebut belum diatur mengenai jangka waktu pemberian tanggapan oleh Otoritas Jasa 
Keuangan dari aduan yang telah Keuangan belum maksimal memasukan disampaikan Konsumen dalam konsep utilitarianisme.

peraturan tersebut, inilah yang bisa disimpulkan konsep utilitarianisme belum maksimal diterapkan karena belum mampu menghasilkan pleasure atau total utility terbesar bagi konsumen

\section{Saran}

Peraturan Otoritas Jasa Keuangan Nomor 1/POJK.07/2013 tentang

Perlindungan Konsumen Sektor Jasa Keuangan yakni tidak tercapainya hak Konsumen untuk memperoleh kenyamanan dan kepastian informasi mengenai tindak lanjut atas aduan yang telah disampaikan kepada Otoritas Jasa Keuangan untuk penyelesaian sengketa Konsumen, tidak tercapainya hak tersebut menyebabkan menurunnya tingkat kerpercayaan Konsumen terhadap Otoritas Jasa Keuangan sebagai institusi atau lembaga yang memiliki tujuan untuk melindungi kepentingan Konsumen di sektor jasa keuangan, dari kajian Peraturan Otoritas Jasa Keuangan Nomor 1/POJK.07/2013 Tentang Perlindungan Konsumen Sektor Jasa

\section{DAFTAR PUSTAKA}

Abdul Halim Barkatullah dan Teguh Prasetyo, 2005, Bisnis Ecommerce: Studi Sistem Keamanan dan hukum di Indonesia, Pustaka Pelajar, Yogyakarta, hlm 1.

Betham, Jeremy, An Introduction to the Principle of Morals and Legislation, Batoche Books, Kitchener, 2000)

Carl Joachim Friedrich, Filsafat Hukum Perspektif Historis, Bandung: Nuansa dan Nusamedia, 2004, h. 25

Irma Muzdalifa, Inayah Aulia Rahma, Bella Gita Novalia, Peran Fintech Dalam Meningkatkan Keuangan Inklusif Pada UMKM di Indonesia, Jurnal Masharif alSyariah: Jurnal Ekonomi dan Perbankan Syariah Vol. 3, No. 1, 2018 
John Rawls, A Theory of Justice, Cambridge,

Massa Chusetts, The Belknap Press of Theresia Anita Christiani, 2016, Harvard University press, 1971, p.60. Bank Indonesia dan Otoritas Lihat pula terjemahan ke bahasa Jasa Keuangan Dalam Indonesia oleh Uzair Fauzan dan Perspektif Hukum, Cahaya Heru Prasetyo,2006, Teori Keadilan, Atma Pustaka, Yogyakarta, Dasar-dasar Filsafat Politik untuk hlm. 81.

Mewujudkan Kesejahteraan Sosial dalam Negara, cet-1, Yogyakarta: Pustaka Pelajar., h. 72

Jonker Sihombing, 2012, Jurnal Hukum Bisnis "Analisis Hukum Otoritas Jasa Keuangan dan Pengawasan Pasar Modal", Volume 31 No.1 Tahun 2012, hlm.16.

Lihat Pasal 1 angka 3 Peraturan Otoritas Jasa Keuangan No. 77/POJK.01/2016 1998 tentang Layanan Pinjam Meminjam Uang Berbasis Teknologi.

Mill, John Stuart, Utilitarianisme, Batoche Books, Kitchener, 2001)

Shidarta, Hukum Perlindungan Konsumen Indonesia, PT Grasindo, Jakarta, 2006, hal 61

Sumber dari LBH Jakarta, Nopember , 2018 